period of five years, we see Marić becoming more unsure of herself, unsure of her place in Einstein's life, pregnant, carrying their illegitimate child on her own while Einstein is employed elsewhere, giving birth without him being there and painfully giving up the baby Liserl for adoption. The letters end with Marić pregnant again, Einstein working at his job in the Swiss patent office, her worried that he will be angry about her being pregnant, he reassuring her: "I'm not the least bit angry that poor Dollie is hatching a new chick. I'm happy about it and had already given some thought to whether I shouldn't see to it that you get a new Liserl. After all you shouldn't be denied that which is the right of all women" (letter 54).

One gets the unmistakeable impression that Einstein grew stronger through his relationship with Marić while she increasingly felt weakened and despairing. There is a deep melancholy in this picture of Einstein's life before he became a star.

Like most collections of letters of leading public figures, these are well worth reading. But we must ask: what are we doing delving into Einstein's love life? Aren't we like Madonna fans, fascinated by our star's stardom? Do these letters tell us what we really want to know?

To understand Einstein we need to understand stardom. We need not the Einstein papers but the newspapers. What has been the role of the media in creating the Einstein legend? What have we been responding to in this myth of the man without socks, the mysterious icon of pure thought? These letters show that, like the luminiferous ether, the Einstein we seek does not exist except in our minds. The mystery of Einstein is the way we have made him incomprehensible. Einstein's achievement, a masterpiece of human understanding, has been turned on its head to become a symbol for the impossible to understand. How did this happen?

Joseph Schwartz is at 2 Lancaster Drive, London NW2 4HA, UK.

\section{Scientism disguised?}

\section{John Polkinghorne}

The Unnatural Nature of Science: Why Science Does Not Make (Common) Sense. By Lewis Wolpert. Faber and Faber: 1992. Pp. 191. £14.99, $\$ 22.95$.

THE unnaturalness of science is held to lie both in the superior clarity of its thought over everyday notions (exemplified, for instance, by common-sense misapprehensions about probabilistic reasoning) and in the counterintuitive character of regimes far from common experience (such as the quantum world). This unnaturalness is to be commended, and Lewis Wolpert's book is a kind of hymn of praise from one of science's practitioners. He rightly distinguishes science from technology, characterizing the scientific aim as the understanding of the world, not its manipulation. It all started in Greece, but Wolpert acknowledges that an essential development occurred in seventeenth-century Europe with the turn to empirical investigation. $\mathrm{He}$ is sufficiently candid to recognize that there was religious encouragement to regard the world as rationally structured, but he fails to notice that the idea of the Creator's freedom of action, enshrined in the Judaeo-Christian-Islamic tradition, implied that one had actually to look to see what order He had chosen to create.

Wolpert is good about scientific creativity, recognizing that it requires a to a guest who is entertaining, slightly relentless and - let's face it - a mite opinionated. The superiority of science is ruthlessly asserted. "Scientific knowledge is special and privileged - in the sense that it provides our best understanding of the world." One cannot deny that science provides our best understanding of some aspects of the world, but its success is purchased by the limitation of its ambition. Essentially it is concerned only with certain kinds of impersonal, largely repeatable experience. But a painting is much more than a collection of specks of paint of known chemical composition, and there is a great deal more to human experience than science is able to tackle. Wolpert makes the astonishing mistake of equating the method of investigation with the actual nature of reality. $\mathrm{He}$ says, "Any philosophy that is at its core holistic must tend to be anti-science, because it precludes studying parts of a system separately".

Even within science, it is absurd to adopt such a reductionist stance. What if there are holistic laws of nature, such as organizing principles working in the direction of increasing complexity? They will have to be sought through new methodologies, but our concern as scientists must be to respond adequately to the way the physical world actually is. In fact, twentieth-century physical science has seen the death of mere mechanism and the discovery of an interconnectedness (nonlocality) in the fabric of the world.

Wolpert is at his worst when he speaks of religion. There is an assertive dismissiveness ("religious belief is incompatible with science"), derived from a caricature picture ("religion is based on unquestioning certainties"). His treatment of theological thought is as crude an abuse as is the creationists' misuse of scientific thought. Wolpert acknowledges with Tolstoy that "science does not tell us how to live". His answer to moral issues seems to be ultimately the social endorsement of the vox populi. Yet his sensitive discussion of the mistakes of the eugenics movement shows that he would not have accepted such policies even if they were endorsed by society (as they were in Nazi Germany). He should think a bit more about what is the source of our intuition of the value of human individuals.

Beneath the civilized discourse of this entertaining book there is a note of unconscious arrogance. The science is tinged with scientism ('science is all') in a way that fuels the fires stoked by the likes of Brian Appleyard or Mary Midgley.

John Polkinghorne is President of Queens' College, Cambridge CB3 9ET, UK.

NATURE · VOL 360 - 26 NOVEMBER 1992 